\title{
On the Statistical Investigation of Fall Velocity of Snowflakes
}

\author{
by \\ Yoshio Sasyo and Takayo Matsuo
}

(Received November 15, 1979)

\begin{abstract}
Fall velocity, mass and cross-sectional area of snowflakes are simultaneously observed in order to obtain the conditional probability function of fall velocity for a given mass.

The results are summarized as follow:

1) The frequency histograms of the mass, of the cross-sectional area and of the fall velocity are obtained for 4 snowfalls (see Fig. 3). The mode and average of the masses, of the cross-sectional areas and of the fall velocities over all snowfalls are $0.5 \mathrm{mg}, 3.6 \mathrm{mg}$ $1.5 \mathrm{~mm}^{2}, 48 \mathrm{~mm}^{2}$ and $70-80 \mathrm{~cm} / \mathrm{s}, 100 \mathrm{~cm} / \mathrm{s}$ respectively. These values may be considered to represent the typical properties of snowflakes observed in the Hokuriku district.

2) The population containing the data of all snowfalls is divided into sub-populations by the interval of mass of $1 \mathrm{mg}$ successively, and the conditional probability function of fall velocity is separately determined for each sub-population. These conditional probability functions can be expressed by a linear combination of several normal distributions with few exceptions. Of these normal distributions, there are two main normal distributions and each of them contributes to the corresponding conditional probability function at the rate of $30 \%$ or more.

3) For each sub-population, the average fall velocity of the normal distribution depends on the mass, though the standard deviation is roughly constant $(12 \mathrm{~cm} / \mathrm{s})$ regardless of the mass.

4) The relationship between the cross-sectional area $S\left(\mathrm{~mm}^{2}\right)$ and the mass $M(\mathrm{mg})$ is shown by the following equation on the average:
\end{abstract}

$$
\bar{M}=0.012 \bar{S}^{3 / 2} \text {. }
$$

\section{Introduction}

Empirical formulas of the fall velocity of a snowflake have been proposed by many authors so far. LANGLEBEN (1954) expressed the fall velocity as a power function of its melted diameter, i. e.

$$
V=k D^{n},
$$

where $V$ and $D$ are the fall velocity $(\mathrm{cm} / \mathrm{s})$ and the melted diameter $(\mathrm{cm})$ of the snowflake respectively, and $k$ and $n$ are constants for a given type of snowfall. MAGONO (1953, 54) observed fall velocity photographically and expressed it as a function of the dimension. MAGONO and NAKAMURA (1965) found a relation between fall velocity and density. These relations were also discussed by FUJIWARA (1975) theoretically.

For the calculation of the growth rate of the snowflake and the radar studies of the snow pattern, LANGLEBEN's formula has been most widely used. Many authors measured the fall velocity for various snowfalls and arranged their results according to LANGLEBEN's formula, (IMAI et al. (1955), Litovinov (1956), KAJIKAWA (1974) and so on). 
On the other hand, SASYō (1972) carried out stereographical analyses of the motion of falling snowflakes and obtained the following results :

1) The momentary velocity of an individual falling snowflake has a fluctuation of about $5 \mathrm{~cm} / \mathrm{s}$ in standard deviation and the fluctuation plays an important role in the initial stage of snowflake formation.

2) The average fall velocity is not determined uniquely even if the mass of snowflakes is fixed but must be determined statistically.

3) It was found that the statistical diversity of the average fall velocity also plays an important role in the growth of a snowflake, but we could not estimate the effect of the diversity on the growth of a snowflake, because the probability function of the average fall velocity was not obtained at that time.

Recently we have measured the fall velocity, the mass and the cross-sectional area of snowflakes simultaneously. From the measurements, we obtained the probability function of the average fall velocity of the snowflake.

In this paper, we will show that the conditional probability function of fall velocity for a given mass can be approximated properly in terms of a linear combination of the normal distribution function.

\section{Instrument and procedure}

The fall velocity, cross-sectional area and mass of the snowflake are observed in a vertical tunnel in which the motion is free from turbulent disturbance. The arrangement of the instruments is illustrated in Fig. 1. A tunnel of $50 \times 50 \mathrm{~cm}^{2}$ in cross section and $120 \mathrm{~cm}$ in depth is made with blackened wooden and transparent acrylic boards. Three photoswitches A, B and C are set at suitable intervals in the tunnel. Each photoswitch has an opening of $15 \mathrm{~cm}$ square and a bead light-emitting diode and phototransistors are arranged in a row on either side of the opening to act as a photocoupler. A

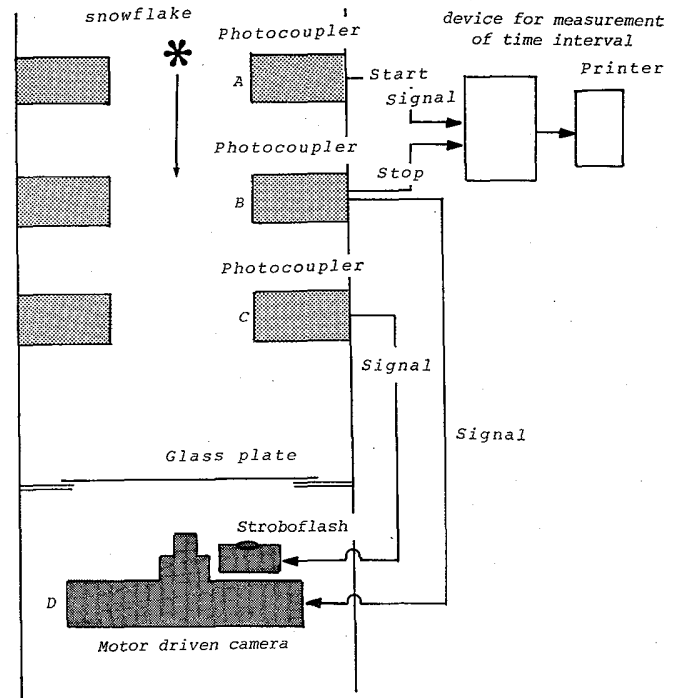

Fig. 1. The arrangement of the instruments.

moter-driven camera with a flash gun "D" is set, face upward, at the bottom of the tunnel in order to take photographs of the cross section of the falling snowflake.

When the falling snowflake passes through the photoswitch $A$, the photoswitch sends a signal to a device which measures the time interval and the device begins to count time. After that, the snowflake passes through the photoswitch $\mathrm{B}$, a signal makes the device stop to count time and open the shutter of the motor-driven camera " $D$ " at the same time. When the snowflake passes through the photoswitch $\mathrm{C}$, the flash gun of the motor-driven camera operates by receiving the signal in the same way as the above. In this way the fall velocity of the snowflake can be obtained from the time interval traveling and the distance between the $\mathrm{A}$ and $B$ photoswitches, and the cross section of the snowflake at the level of the photoswitch $\mathrm{C}$ is instantaneously photographed. Finally, the snowflake is collected on a hygroscopic glass plate and its mass is measured by the absorbent paper method.

\section{The synoptic situation on the snow falls}

The synoptic situations of the snowfalls are obtained by the vertical time-sections of 
temperature and relative humidity at Wajima; which is located about $170 \mathrm{~km}$ west of Nagaoka city, during the observation periods. Fig. 2-a and $-b$ show the vertical time sections. In these figures, the ordinate and abscissa indicate the atmospheric pressure $(\mathrm{mb})$ and time respectively. The isotherm and isohume are represented by the full and dotted lines respectively. The points of equal supersaturation with respect to the ice plane are joined by a dot-dash line and the area of supersaturation is stippled. The durations of snowfall are shown as the intervals between two dotted lines in the upper part of the figure and the types of major precipitation particles are also shown by precipitation symbols in the duration.

a) The case of 27 th to 28 th of Jan. 1978 (27th, $22 \mathrm{~h} 30 \mathrm{~m}-28 \mathrm{th}, 07 \mathrm{~h} 00 \mathrm{~m}$ )

The snowfall was accompanied by a passage of a cyclone over the Japan Sea. In the beginning, sleet was observed in the snowfall (on 27th) when the atmosphere was warm and moist from the ground up to $700 \mathrm{mb}$ level owing to southerly wind in the lower level. As the cyclone passed eastward, the temperature decreased gradually and no sleet was observed. Average surface temperature and relative humidity in this period were about $1.2^{\circ} \mathrm{C}$ and $94 \%$ respectively. Let us call the snowfall as the case of 28 th hereafter.

b) The case of 29th of Jan. $1978(09 \mathrm{~h}$ $30 \mathrm{~m}-19$ h $00 \mathrm{~m}$ )

A high pressure located in the west of the China continent extended over the Japan Sea area to the northern part of the Japanese Islands. The air temperature and humidity below $800 \mathrm{mb}$ level were lower by $2.0 \sim 3.0^{\circ} \mathrm{C}$ and about $10 \%$, respectively, than those of 27th 28 th. Average surface temperature and relative humidity were $-1.0^{\circ} \mathrm{C}$ and $80 \%$ respectively.

c) The case of 30th of Jan. $1978(10 \mathrm{~h}$ $20 \mathrm{~m}-10 \mathrm{~h} 50 \mathrm{~m}$ )

The atmospheric condition is characterized by comparatively warm air in the lower atmosphere due to a weak cyclone located on the Japan Sea and very cold air above
$700 \mathrm{mb}$ level due to the outbreak of cold air from a Siberian high pressure. Average surface temperature and relative humidity were $-1.7^{\circ} \mathrm{C}$ and $90 \%$ respectively. On the 29 th and the 30th of Jan. 1978, snowflakes were observed with surface temperatures below freezing point. We can therefore regard both snowflakes as the same category from view point of the snowflakes being in a non-melting situation. Then the data of both days will be collectively discussed and called the case of 30th hereafter.

d) The case of 2nd of Feb. $1979(05 \mathrm{~h}$ $50 \mathrm{~m}-07 \mathrm{~h} 00 \mathrm{~m}$ and $20 \mathrm{~h} 30-22 \mathrm{~h} 40 \mathrm{~m}$ )

The snowfall occurred in the typical winter monsoon pattern, that is, a high pressure in the East China Sea and a cyclone in the Sea of Okhotsk. No synoptic disturbances around the observation site were seen on the weather map on 2nd of Feb. Average surface temperature and relative humidity were $0.7^{\circ} \mathrm{C}$, and $98 \%$ during the first snowfall and $1.0^{\circ} \mathrm{C}$ and $90 \%$ during the second snowfall, respectively.

e) The case of 4th of Feb. 1979 (13 h $30 \mathrm{~m}-17 \mathrm{~h} 34 \mathrm{~m}$ )

The snowfall was associated with a cold front of a cyclone passing over the Japan Sea. A significant temperature drop of about 2 or $3^{\circ} \mathrm{C}$ took place in the lower atmosphere (see isotherm of $-10^{\circ} \mathrm{C}$ in Fig. 2-b). Sleet was observed at the beginning of the snowfall. The surface temperature was about $1.8^{\circ} \mathrm{C}$ at first and then decreased rapidly to $0^{\circ} \mathrm{C}$ at the end. The surface relative humidity was $90 \%$ at first and decreased gradually to $85 \%$ at the end.

f) The case of 6th of Feb. $1979(07 \mathrm{~h}$ $40 \mathrm{~m}-09$ h $40 \mathrm{~m}$ )

The snowfall was associated with convection in the warm sector of a cyclone located over the Japan Sea. The atmosphere was warm and moist from the ground to $700 \mathrm{mb}$ level. Average surface temperature and relative humidity were about $1.2^{\circ} \mathrm{C}$ and $94 \%$ respectively. The data of the day were not separately discussed statistically because of the small sampling number. 


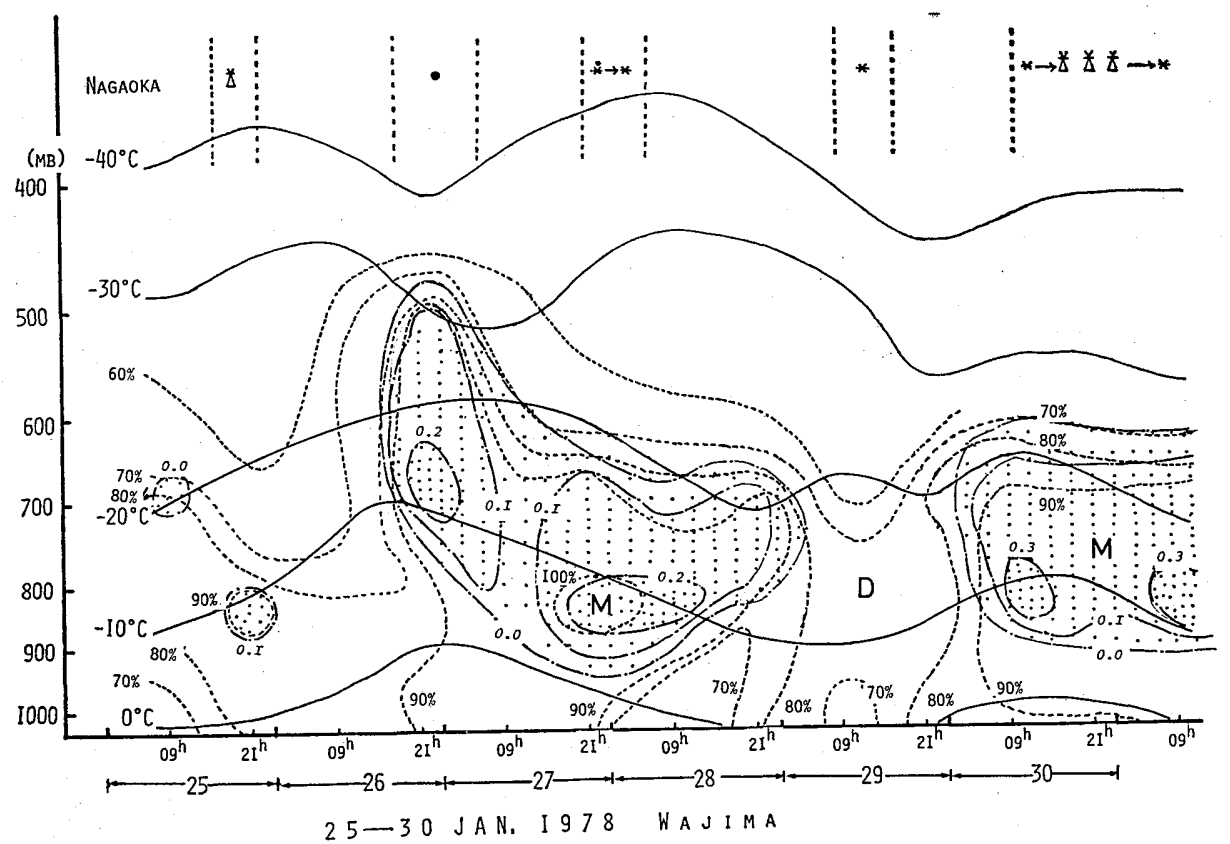

Fig. 2-a. The vertical time-section of temperature and relative humidity at Wajima; during the observation period of 1978 . The coordinate; the atmospheric pressure $(\mathrm{mb})$. The abscissa; time. The full line; the isotherm. The dotted line; the isohume. The dot-dash-line; the equisupersaturation line. The stippled area; the supersaturation area. The duration limited by two dotted vertical lines; the period of snowfall. Symbols (•) rain, (*) sleet, (*) snow,

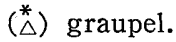

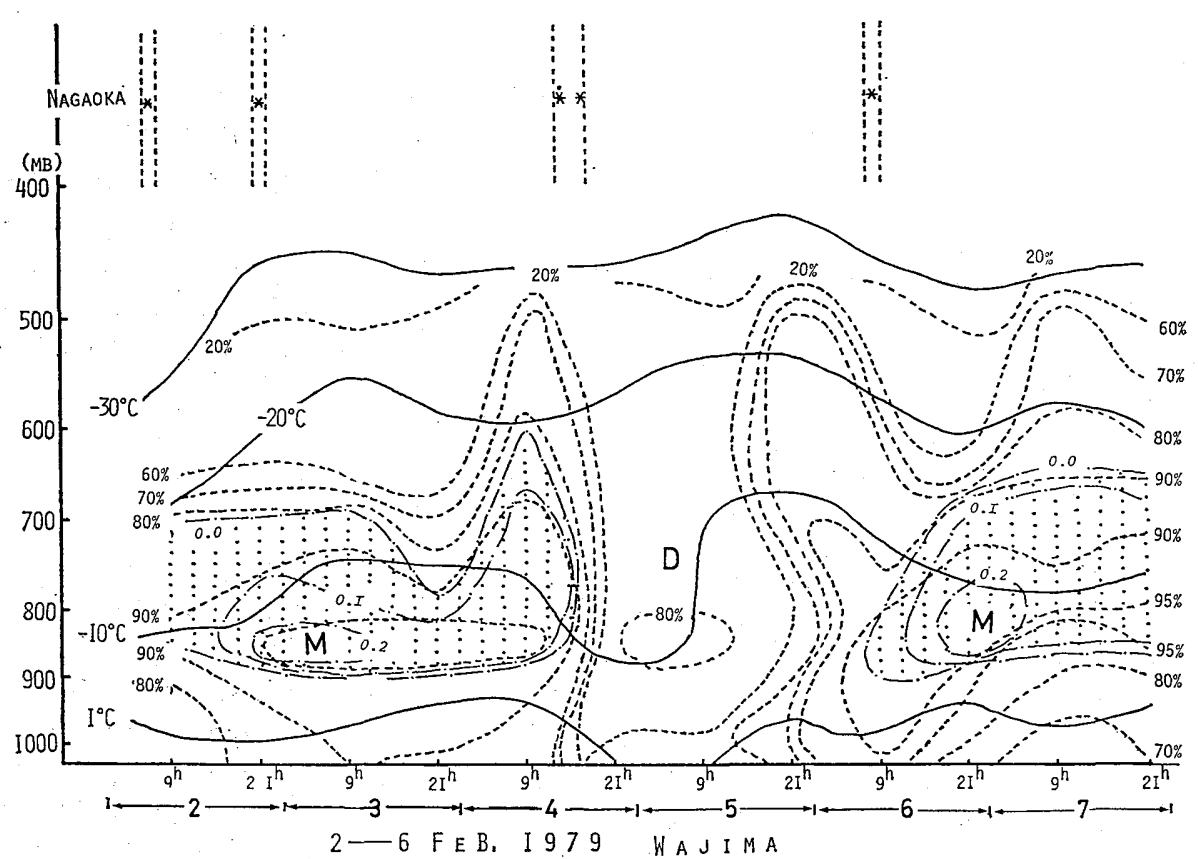

Fig. 2-b. The vertical time-section of temperature and relative humidity at Wajima, during the observation period of 1979 . The symbols are the same as those in Fig. 2-a. 


\section{The population of snowflakes for each snowfall}

The population of snowflakes is characterized by the frequency distribution of the mass, the cross-sectional area, the fall velocity and so on. Fig. 3 shows the frequency distribution in histograms. In the figure, the histograms $-M,-S$ and $-V$ indicate the frequency distribution of the mass, the cross-sectional area and the fall velocity respectively. The three histograms at the top are the frequency distributions of the 28th of Jan. 1978, 2nd, 3rd and those at the bottom those of 29th of Jan. 1978, 2nd of Feb. 1979 and 4th of Feb. 1979 respectively. The figures on the abscissa in the histogram $-M 0,1,2, \cdots$ correspond respectively to the interval of mass $0<M<1 \mathrm{mg}, 1 \mathrm{mg} \leqq M<$ $2 \mathrm{mg}, \quad 2 \mathrm{mg} \leqq M<3 \mathrm{mg} \cdots$ and so on. The
M

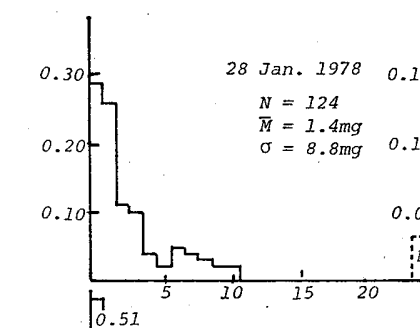

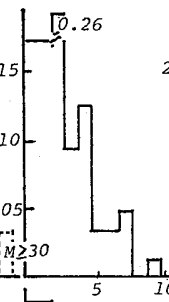

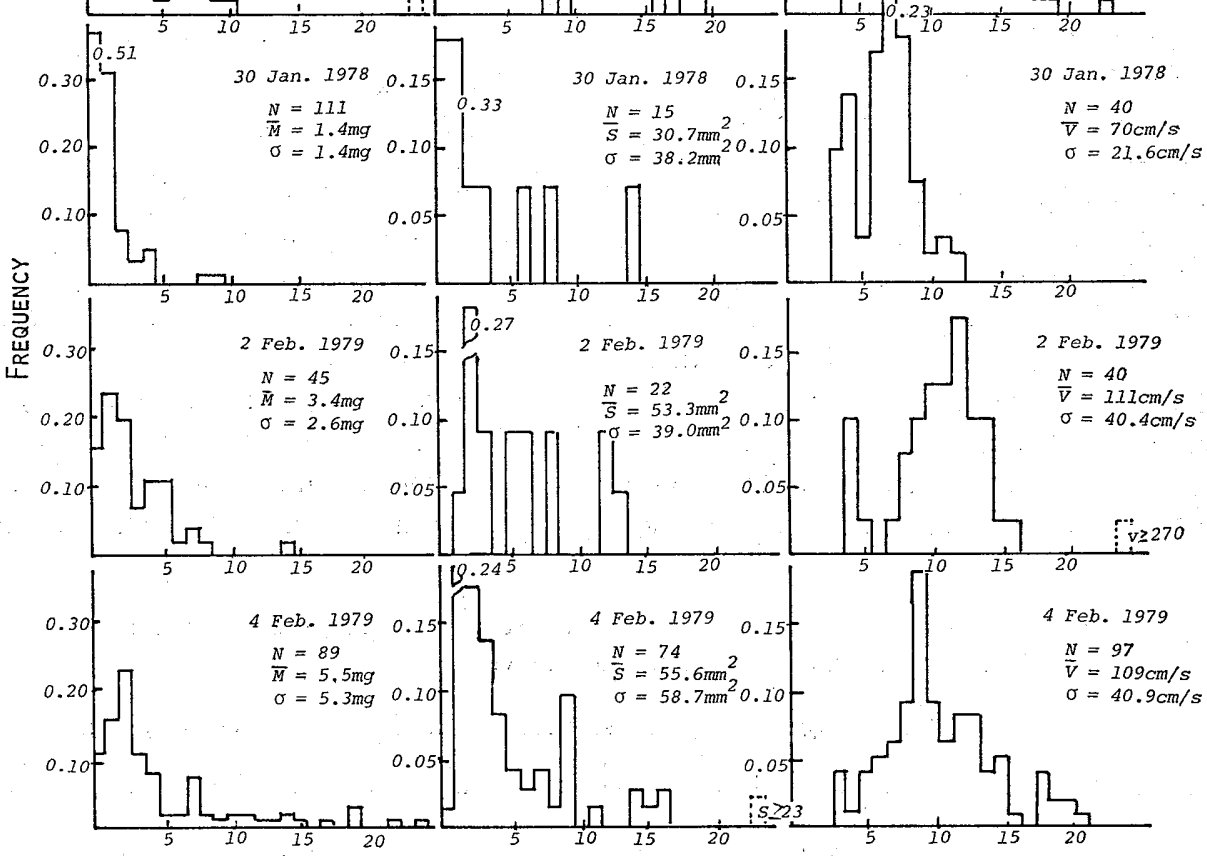

INDEX OF CLASSIFIED MASS

Fig. 3. The frequency histograms of the mass, the cross-sectional area and the fall velocity, respectively. Three histograms in the top line are the frequency distribution on 28th of Jan. 1978, 2nd, 3rd and bottom line those on 30th of Jan. 1978, 2nd of Feb. 1979 and 4th of Feb. 1979 respectively. The figures in histogram- $M, 0,1,2, \cdots$ correspond to the mass intervals of $0<M<1 \mathrm{mg}, 1 \mathrm{mg} \leqq M<2 \mathrm{mg}, 2 \mathrm{mg} \leqq M<3 \mathrm{mg}, \cdots$ respectively. The figures in histogram-S and histogram $-V$ indicate $0<S<10 \mathrm{~mm}^{2}, \quad 10 \mathrm{~mm}^{2} \leqq S<20 \mathrm{~mm}^{2}, \quad 20 \mathrm{~mm}^{2} \leqq S<30 \mathrm{~mm}^{2} \cdots$ and $0<V<10 \mathrm{~cm} / \mathrm{s}, \quad 10 \mathrm{~cm} / \mathrm{s} \leqq V<20 \mathrm{~cm} / \mathrm{s}, \quad 20 \mathrm{~cm} / \mathrm{s} \leqq V<30 \mathrm{~cm} / \mathrm{s}$ respectively. The number of utilized data, the average values and the standard deviations are listed on the right at the top of each histogram. 
figures in the histograms $-S$ and $-V$ correspond respectively to $0 \mathrm{~mm}^{2}<S<10 \mathrm{~mm}^{2}$, $10 \mathrm{~mm}^{2} \leqq S<20 \mathrm{~mm}^{2}, 20 \mathrm{~mm}^{2} \leqq S<30 \mathrm{~mm}^{2}, \cdots$ and so on and $0 \mathrm{~cm} / \mathrm{s}<V<10 \mathrm{~cm} / \mathrm{s}, 10 \mathrm{~cm} / \mathrm{s}$ $\leqq V<20 \mathrm{~cm} / \mathrm{s}, \quad 20 \mathrm{~cm} / \mathrm{s} \leqq V<30 \mathrm{~cm} / \mathrm{s}, \cdots$ and so on.

The number of the utilized data, the average values and the standard deviations are shown in each histogram. There are some differences in the number of the utilized data in the three distributions on the same day, because the mass, the cross-sectional area and the fall velocity of individual snowflakes were not always observed simultaneously.

The trial of every histogram elongates in the positive direction of the abscissa, namely there are always a few snowflakes whose mass, cross-sectional area and fall velocity are considerably larger than the average value.

The statistical parameters of these frequency distributions are also listed in Table 1 , which shows that the maximum values of the mass and of the cross-sectional area are 5 times their average values, but that the maximum fall velocity is only 2 times the average value. Furthermore, Table 1 indicates that the standard deviations of the mass and of the cross-sectional area are almost equal to their average values. On the contrary, the fall velocity is only one third. Namely, the frequency distribution of the fall velocity is narrower than those of the mass and of the cross-sectional area. It is noticeable that the snowflakes on the 30th of Feb. 1978, which grew under the atmospheric conditions of the lowest temperature and humidity, have the smallest values of mass, cross-sectional area and fall velocity in comparison with the other cases.

The bottom in Table 1 indicates the statistical parameters of the histograms for the population which contain all observed data. The population may be considered to represent the typical features of snowflakes in the Hokuriku district. They have a modal mass, cross-sectional area and fall velocity of $0.5 \mathrm{mg}, 15 \mathrm{~mm}^{2}$ and $70-80 \mathrm{~cm} / \mathrm{s}$ and the corresponding average values are $3.6 \mathrm{mg}, 48 \mathrm{~mm}^{2}$ and $100 \mathrm{~cm} / \mathrm{s}$, respectively.

\section{The relation between fall velocity and mass of the snowflake, $V-M$ relation}

The relation between fall velocity and mass of the snowflake ( $V-M$ relation) and that between fall velocity and cross-sectional area $(V-S$ relation) are immediately obtained from our observations.

We will pay attention mainly to the $V-M$ relation hereafter, because it is convenient for the discussion of the growth of the snowflake. The $V-M$ relation can easily

Table 1 The statistical paramenters of the frequency histograms of the mass, the cross-sectional area and the fall velocity.

\begin{tabular}{|c|c|c|c|c|c|c|c|c|c|c|c|c|}
\hline & \multicolumn{4}{|c|}{ Mass (mg) } & \multicolumn{4}{|c|}{ Cross Section $\left(\mathrm{mm}^{2}\right)$} & \multicolumn{4}{|c|}{ Fall Velocity $(\mathrm{cm} / \mathrm{s})$} \\
\hline Date & Max. & Mod. & Mean & Dev. & Max. & Mod. & Mean & Dev. & Max. & Mod. & Mean & Dev. \\
\hline $\begin{array}{c}1978 \\
28 \text { Jan. }\end{array}$ & 61.5 & 0.5 & 4.2 & 8.8 & 245 & 2 & 40.2 & 47.1 & 236 & 12 & 116 & 38.6 \\
\hline $\begin{array}{c}1978 \\
30 \text { Jan. }\end{array}$ & 9.0 & 0.5 & 1.4 & 1.4 & 148 & 0.1 & 30.7 & 38.2 & 126 & 7 & 70 & 21.6 \\
\hline $\begin{array}{l}1979 \\
2 \text { Feb. }\end{array}$ & 14.0 & 1,5 & 3.4 & 2.6 & 132 & 2 & 53.3 & 39.0 & 277 & 12 & 112 & 40.4 \\
\hline $\begin{array}{l}1979 \\
4 \mathrm{Feb} .\end{array}$ & 24.0 & 2.5 & 5.3 & 5.3 & 400 & 1 & 55.6 & 57.8 & 198 & 9 & 109 & 40.9 \\
\hline Total & 61.5 & 0.5 & 3.6 & 5.7 & 400 & 1 & 48.4 & 55.1 & 277 & $7,8,9$ & 100.3 & 40.7 \\
\hline
\end{tabular}


be transformed into LANGLEBEN's formula $\left(\bar{V}=K D^{-n}\right)$ and compared with other authors' results.

The $V-M$ relation for all snowfalls are separately shown in Figs. 4a-4d. In these figures, the ordinates indicate the fall velocities and the abscissas, the masses. The figures a-d, correspond to those on 28th, 30 th of Jan. 1978, 2nd, 4th and 6th of Feb. 1979 in that order. The time changes of the surface temperature on each day are shown in the lower part of the corresponding figure. As is obvious from these figures, the fall velocity and mass of the snowflake at temperature $0^{\circ} \mathrm{C}$ and below (30th of Jan. 1978) are considerably small in comparison with those at temperatures above $0^{\circ} \mathrm{C}$.

The figures show also wide dispersion, which generally becomes large in the region of small mass. We can suppose several causes for this, the chief of which seems to be the melting of the snowflake. As an example, let us consider the case of 4 th of Feb. 1979 (Fig. 4-d). As mensioned above, the surface temperature and humidity on this day decreased from $1.8^{\circ} \mathrm{C}$ and $90 \%$ to $0^{\circ} \mathrm{C}$ and below and 80\%, respectively, and the snow particles changed from sleet to dry snowflakes with the decreasing of the temperature. The majority of the snowflakes belong to the region " $A$ " and " $D$ ". They were observed from $14 \mathrm{~h} 00 \mathrm{~m}$ to $17 \mathrm{~h} 34 \mathrm{~m}$, when the average temperature was about $+1.0^{\circ} \mathrm{C}$. The snowflakes denoted by a full circle in the region " $\mathrm{A}$ " were observed at the temperatures of $0^{\circ} \mathrm{C}$ and below. Some snowflakes denoted by circles in the region "D" were observed from $16 \mathrm{~h} 05 \mathrm{~m}$ to $16 \mathrm{~h}$ $27 \mathrm{~m}$, in which time the temperature, together with humidity, decreased quickly from $0.8^{\circ} \mathrm{C}$ to about $0^{\circ} \mathrm{C}$. We can not fully discuss characters of these snowflakes because we have very poor data on them but it is undeniable that the decreasing of the temperature turned the damp snowflakes into dry ones.

It is interesting that the snowflakes at $0^{\circ} \mathrm{C}$ and below are limited to the region of small mass in comparison with those in the region " $\mathrm{D}$ ". This fact may suggest that snowflakes are apt to be broken up at temperature $0^{\circ} \mathrm{C}$ and below because the adhesional power among the individual snow crystals in the snowflakes becomes weak quickly at that temperature as pointed out by HosLer and JENSEN (1957).

The relation between the surface temperature and the size of snowflake has also been pointed out by MAGANo (1953) though there is some difference between his observation and ours in some respects. He pointed out that the maximum size of snowflakes was observed in the region of $0^{\circ} \mathrm{C} \sim 1.0^{\circ} \mathrm{C}$.

In both regions " $\mathrm{A}$ " and " $\mathrm{D}$ ", the fall velocity shows a tendency to increase with the increasing of the mass.

On the other hand, the full circles in the region "W" correspond to the snowflakes observed in the period from $13 \mathrm{~h} 32 \mathrm{~m}$ to $13 \mathrm{~h} 50 \mathrm{~m}$, in which the average temperature was $+1.5^{\circ} \mathrm{C}$, high temperature keeping on throughout. They were limited within the region of relatively small mass and the fall velocities were larger than those of other snowflakes with the same mass. It is clear that the snowflakes in the region "W" are affected by the melting.

The melting of the snowflake induces the shrinkage of the cross-sectional area and the increase of density. These changes bring the increase of fall velocity of the snowflake. The fall velocity, therefore, ranges from that of a dry snowflake to that of a completely melted snowflake (rain drop) according to the degree of melting.

Assuming that the degree of melting is the ratio of water content in the snowflake to its total mass, the degree of melting will become large with the ratio of the surface area to its total mass under the same environmental condition, because the heat which is dissipated in the melting of snowflake is transferred through its surface. Then, the response of melting for change of the environmental temperature becomes sensitive as the ratio of the surface area to its total mass increases and the effect of melting on fall velocity appears more remarkably on the snowflake of small mass. This may be a 


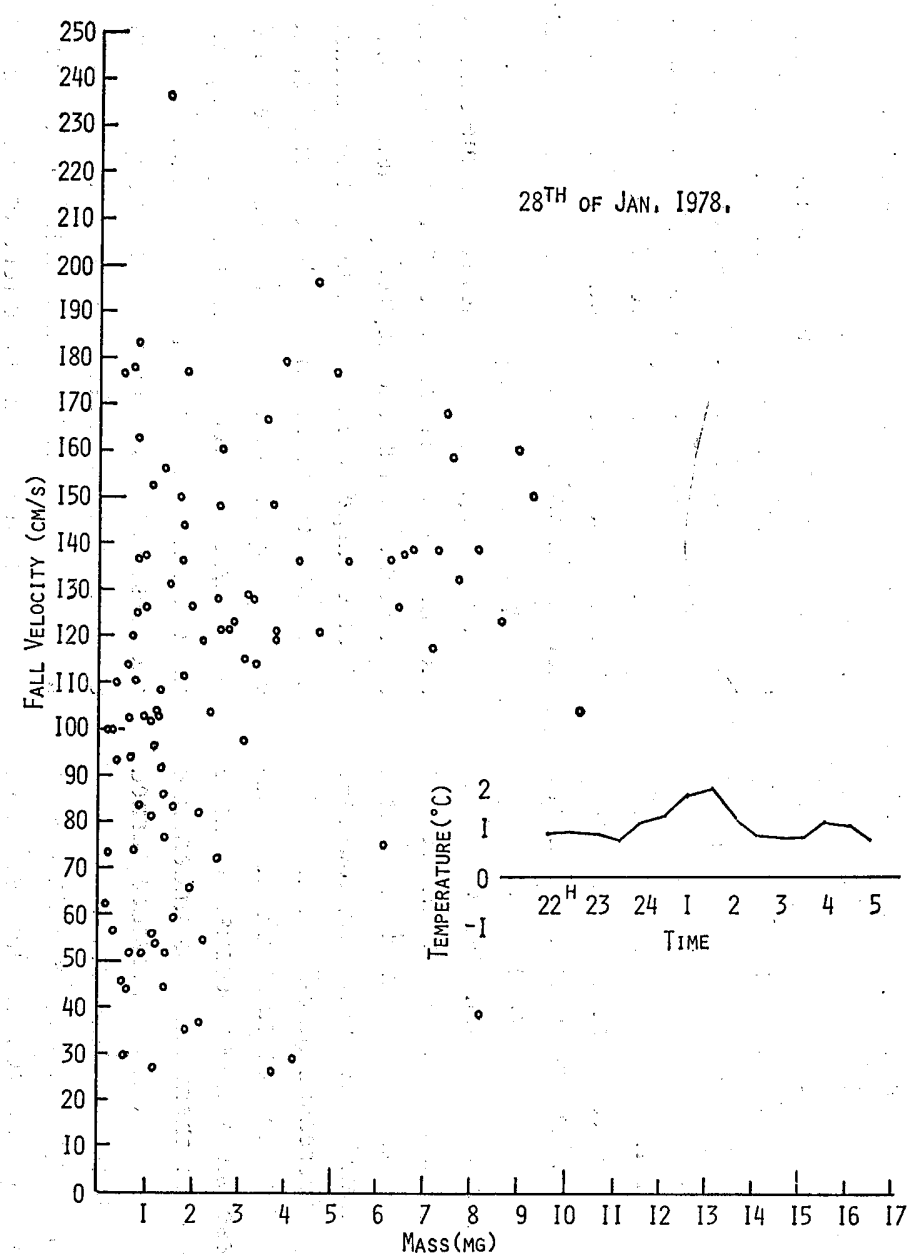

Fig. 4-a The relation between fall velocity and mass ( $V-M$ relation) of on 28th of Jan: 1978. The ordinate and abscissa indicate the fall velocity and the mass repectively. The time change of the surface temperature is also shown on the right in the lower part of the figure.

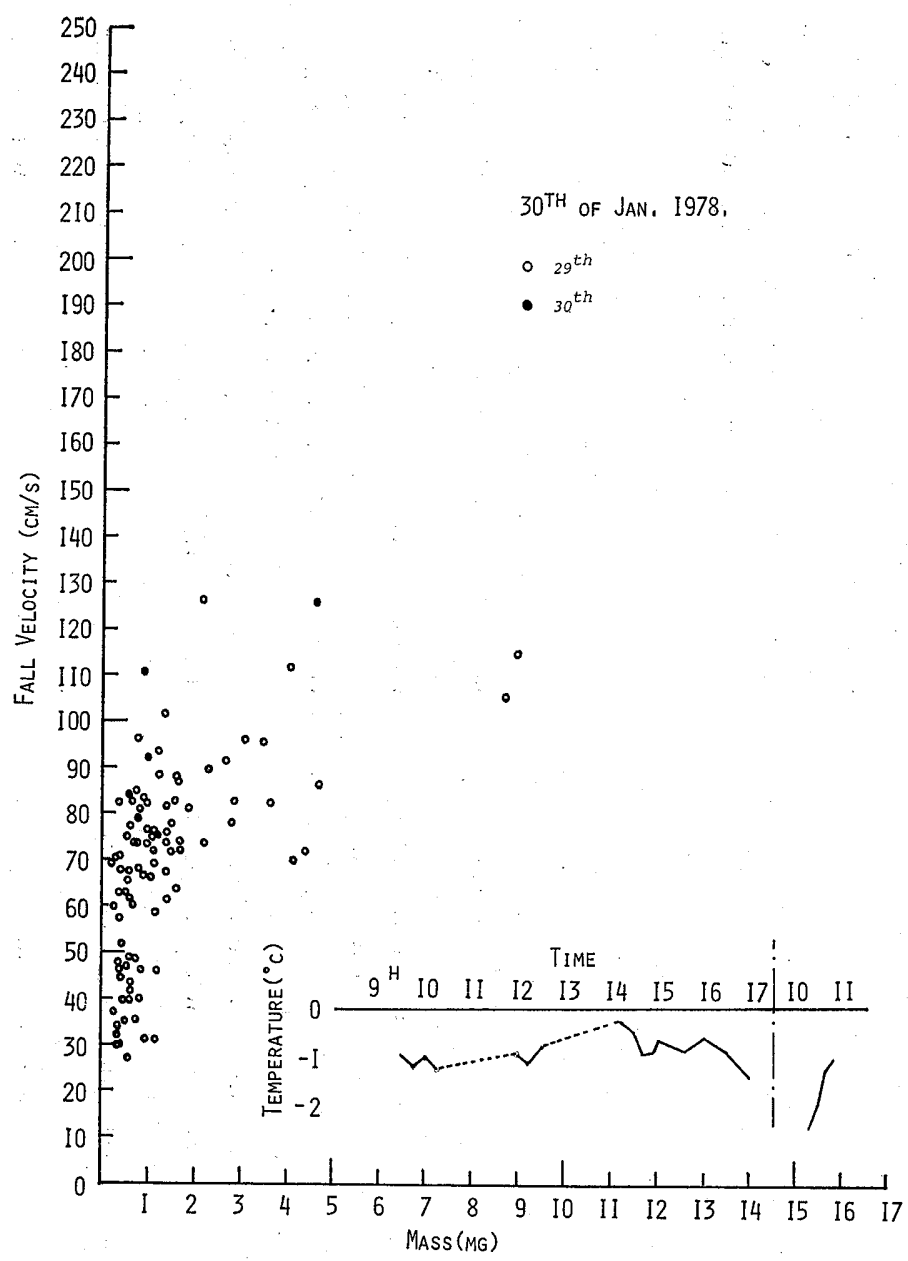

$\vdots$
0
0
0
0
0
0
0
0
$\vdots$
3
3
0
0
0
0

Fig. 4-b The same as Fig. 4-a except for on 30th of Jan. 1978 

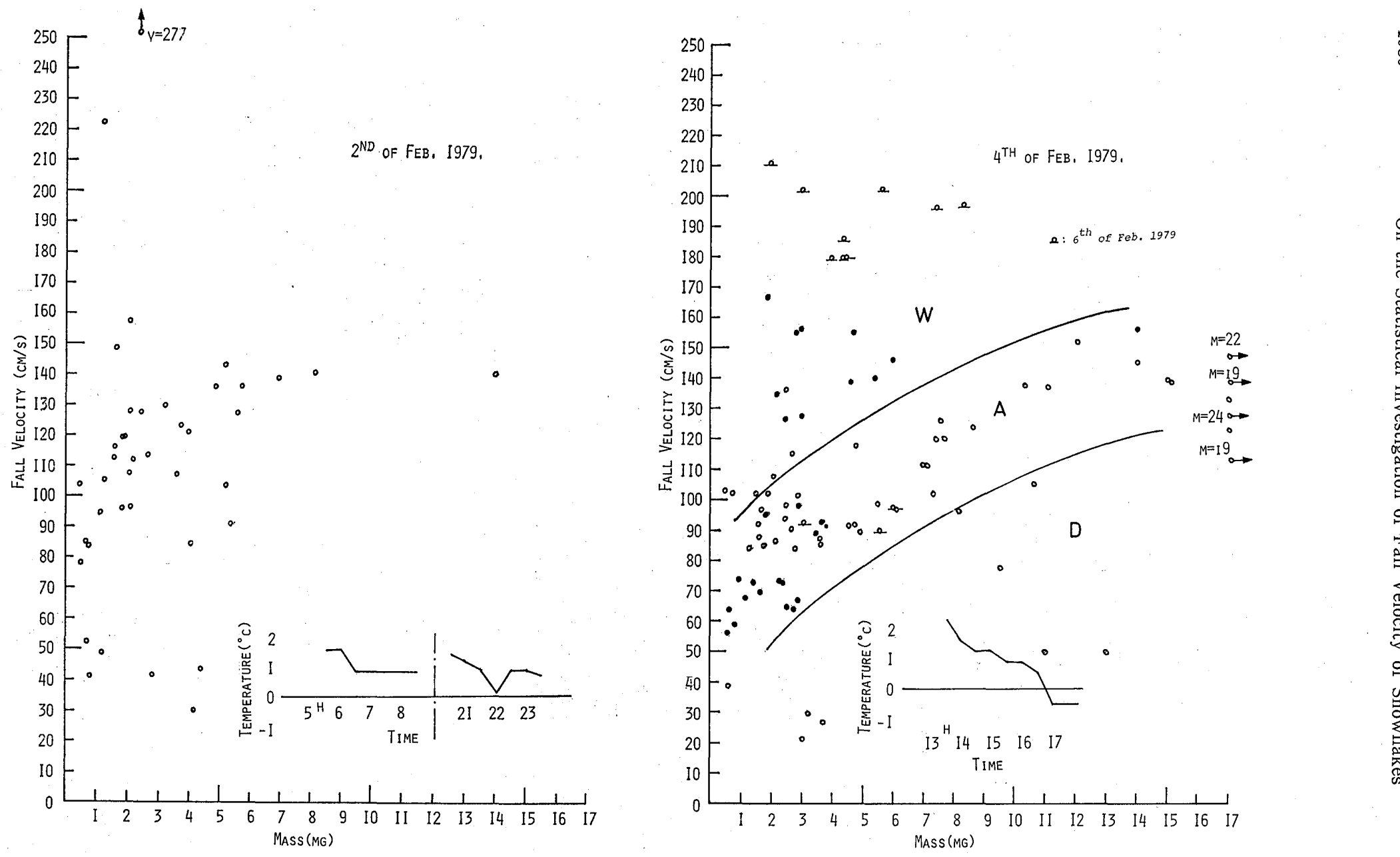

Fig. 4-c. The same as Fig. 4-a except for on 2nd of Feb. 1979.

Fig. 4-d. The same as Fig. 4-a except for on 4th of Feb. 1979.

The snowfiakes indicated by full circles in the region $W$ were observed at an average temperature of $+1.5^{\circ} \mathrm{C}$. Those in the region $A$ were observed at temperatures below $+1.0^{\circ} \mathrm{C}$, those of them indicated by full circles being observed at $0^{\circ} \mathrm{C}$ or below. 
cause of the wide dispersion of fall velocity in the region of small masses.

In this case (4th of Feb. 1979), the snowflakes observed at temperatures above $+1.2^{\circ} \mathrm{C}$ belonged to the region " $\mathrm{W}$ " and those below $+1.2^{\circ} \mathrm{C}$, to the region " $\mathrm{A}$ " and " $\mathrm{D}$ ". Namely, we can say that the critical surface temperature at which the effect of melting on fall velocity becomes remarkable was about $+1.2^{\circ} \mathrm{C}$ but the critical temperature is not always constant in other cases. The fact may suggest that the degree of melting depends not only upon the temperature but other atmospheric conditions such as relative humidity.

In order to find the quantitative relation between dispersion and mass, the standard deviation of fall velocity is shown as a function of the mass in Fig. 5. In this figure, the standard deviations on 28th and 30th of Jan. 1978 can be considered to be examples of damp and dry snowflakes, respectively, as mentioned in section 3. The dry snowflake has a standard deviation of $15 \mathrm{~cm} / \mathrm{s}$ or less regardless of the mass. On the contrary, the damp snowflake has that of about $40 \mathrm{~cm} / \mathrm{s}$ for the mass less than $2 \mathrm{mg}$, approaching that of the dry snowflake with the increase of the mass. The standard deviations on 2 nd Feb. and 4th Feb. lie roughly between those on 28 th and 30 th.

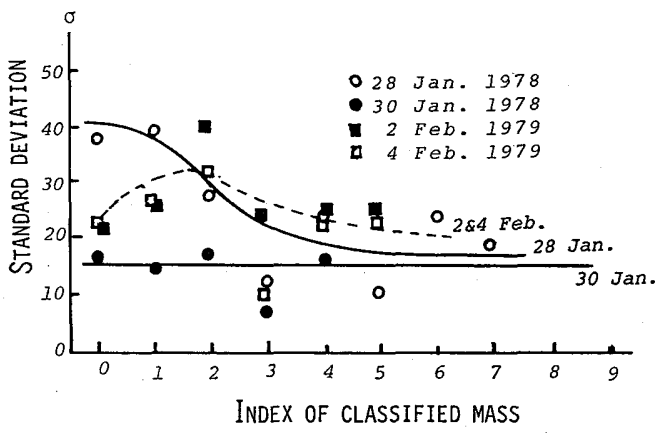

Fig. 5. The standard deviation of the fall velocity as a function of the mass. The ordinate indicates the standard deviation and the figures on the abscissa are the same as in Fig. 3. The meaning of symbols is shown at top right in the figure.
The relations between the average fall velocity and the average melted diameter $(\bar{V}-\bar{D}$ relation) can be easily obtained from the $\bar{V}-\bar{M}$ relation. The $\bar{V}-\bar{D}$ relations for 4 snowfalls are shown in Fig. 6 , the ordinate is the fall velocity and the abscissa, the melted diameter $(\mathrm{cm})$. The relations can be approximated by power function (LANGLEBEN's expression) and compared with other authors' results in Table 2. However, these comparisons may be meaningless unless the physical meaning of LANGLEBEN's expression is clarified.

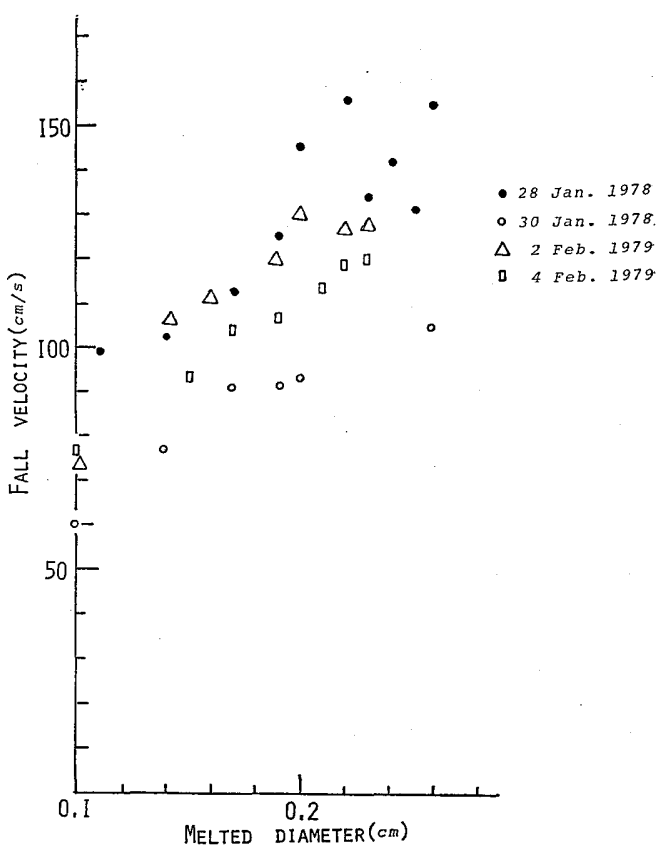

Fig. 6. The relation between the average fall velocity and the average melted diameter ( $\bar{V}-\bar{D}$ relation) for 4 snowfalls. The meaning of symbols is listed at top right.

Table 2 Comparison between constants of $k$ and $n$ in LANGLEBEN's formula for each snowfall observed.

\begin{tabular}{|c|c|c|}
\hline Date & $n$ & $k$ \\
\hline 28 Jan. 1978 & 049 & 299 \\
30 Jan. 1978 & 062 & 253 \\
2 Feb. 1979 & 063 & 360 \\
4 Feb. 1979 & 0.62 & 302 \\
\hline MEAN & 059 & 301 \\
\hline
\end{tabular}


The relation between the fall velocity and the cross-sectional area ( $V-S$ relation) can also be obtained. As an example, the $V-S$ relation obtained by using all data is shown in Fig. 7. In this figure, the ordinate and abscissa indicate the fall velocity and the cross-sectional area respectively and the meaning of symbols is also shown at top right. This relation shows a wider dispersion in comparison with the $V-M$ relation but the dispersion shows the same tendency as the $V-M$ relation: the amount of dispersion becomes larger in the region of the smaller cross-sectional area (small snowflake). The snowflakes surrounded by dotted line are those observed at temperature $0^{\circ} \mathrm{C}$ or below and correspond to those denoted by full circles in region " $\mathrm{A}$ " in Fig. 4-d.

Figs. 4 and 7 suggest that the dry snowflakes observed at relatively low temperatures are small in mass, cross-sectional area and fall velocity. As mentioned above, this fact may suggest that they are apt to break at

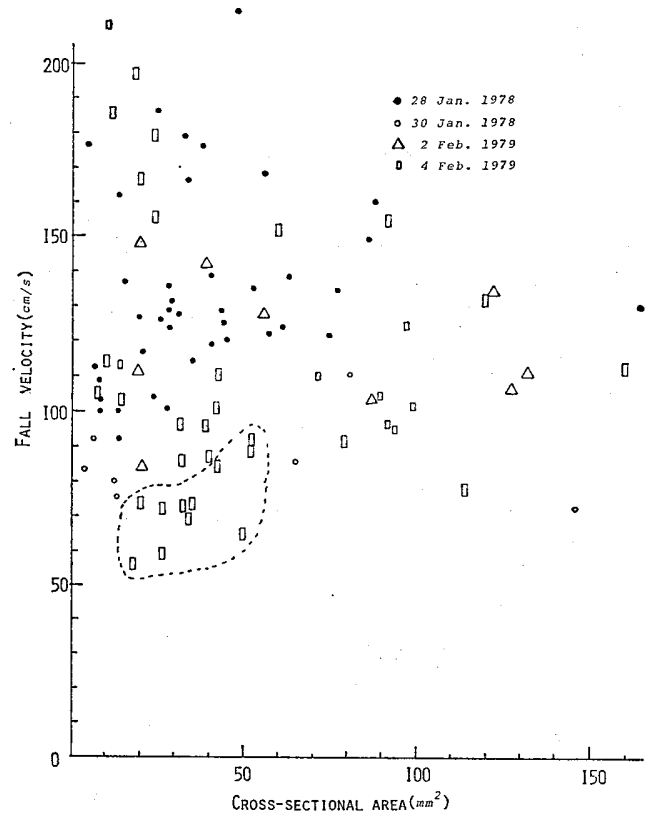

Fig. 7. The relation between the fall velocity and the cross-sectional area $(V-S$ relation). The points in the region surrounded by the dotted line correspond to the snowfiakes represented by full circles in the region A of Fig. 4. low temperatures.

\section{Conditional probability function of fall velocity for a given mass, Velocity distri- bution function}

We must determine the conditional probability function of fall velocity to discuss the growth of a snowflake. We will try to obtain the conditional probability function $P(V / M) \Delta M \Delta V$ with which the fall velocity of snowflakes with mass ranging from $M$ to $M+\Delta M$ lie between $V$ and $V+\Delta V$. In order to obtain the conditional probability function, let us consider the population including all the data, because the individual snowfall is
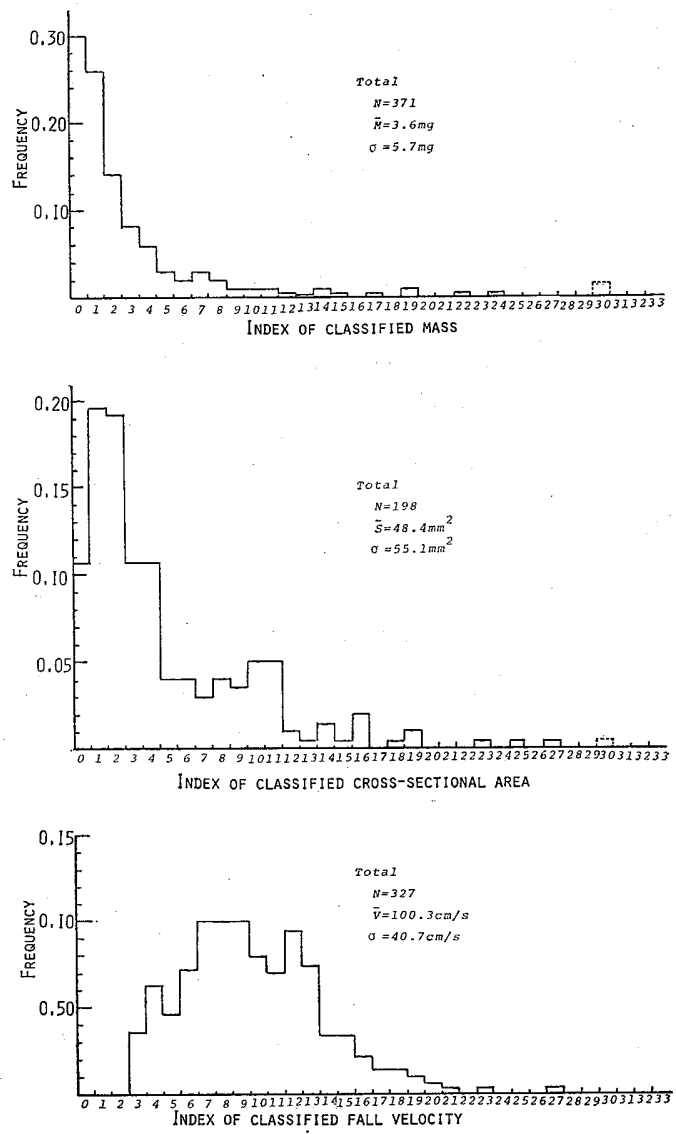

Fig. 8. The frequency histograms of the mass, the cross-sectional area and the fall velocity for the population including all the data observed. The meaning of symbols is the same as in Fig. 3. 
insufficient in the number of data it affords. Fig. 8 shows the frequency histogram of the mass, cross-sectional area and fall velocity for this population. The statistical parameters of these histograms are also summarized

- in the last line of Table 1 . We may consider that these frequency histograms represent the statistical features of typical snowflakes in the Hokuriku district.
The population is divided into sub-populations with the successive mass interval of $1 \mathrm{mg}$; and the frequency distribution of the fall velocity with the velocity interval of $\Delta V=10 \mathrm{~cm} / \mathrm{s}$ is made for the individual subpopulation in the histogram. For example, the histograms for the populations of the mass interval $0<M<1 \mathrm{mg}$ and $4 \mathrm{mg} \leqq M<$ $5 \mathrm{mg}$ are shown in Fig. 9. In this figure,
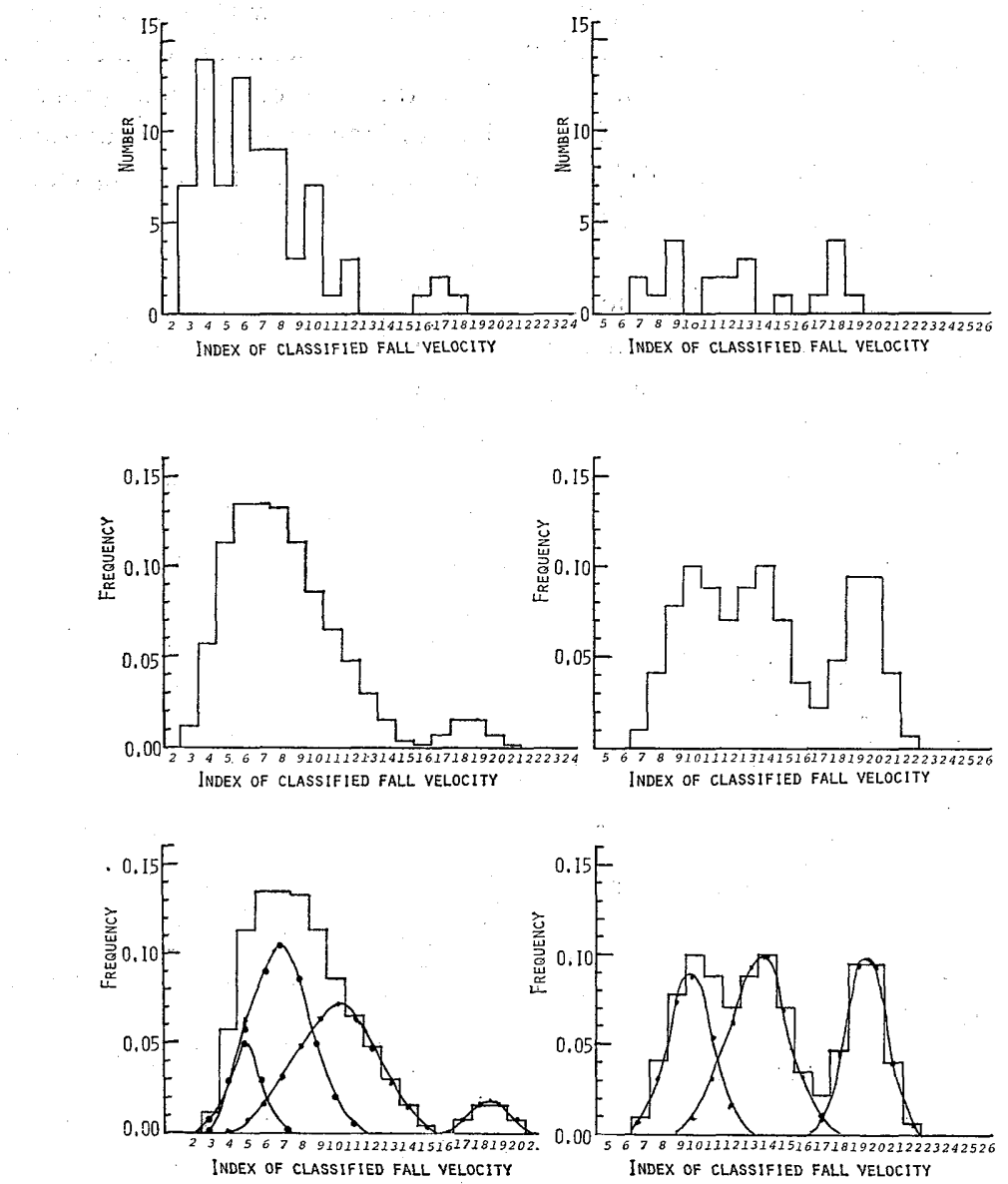

$P(V / 0) \Delta M \Delta V=0.0487 e^{-0.0055(V-55.3)^{2}}$

$$
\begin{aligned}
& +0.1007 e^{-0.0016(V-73.6)^{2}} \\
& +0.0701 e^{-0.0009(V-105.1)^{2}} \\
& +0.0177 e^{-0.0035(V-190.0)^{2}}
\end{aligned}
$$

$$
\begin{aligned}
P(V / 4) \Delta M \Delta V= & 0.0919 e^{-0.0032(V-102.6)^{2}} \\
& +0.1051 e^{-0.0018(V-140.4)^{2}} \\
& +0.1055 e^{-0.0041(V-200.0)^{2}}
\end{aligned}
$$

Fig. 9. The velocity distribution functions for the subpopulation of the mass of $0<M<1 \mathrm{mg}$ and $4 \mathrm{mg} \leqq M<5 \mathrm{mg}$. The former is shown in the left and the latter in the right column. The top histograms show crude frequency distributions and the second the smoothed histograms by the operation of running mean of the crude histograms. The third line is the expression of each velocity distribution function by a linear combination of the normal distributions and the last line their mathematical expressions. 
the frequency distributions of $0<M<1 \mathrm{mg}$ and $4 \mathrm{mg} \leqq M<5 \mathrm{mg}$ are shown in the left and right respectively. The top histograms show the crude frequency distribution and the second the smoothed histograms. These smooth histograms are obtained by carring out three times the smoothing procedure in which the frequency of occurrence is averaged in two adjacent velocity intervals. We can assume the smoothed frequency histogram to be the velocity distribution function for the given mass $P(V / M) \Delta M \Delta V$.

In order to calculate the growth of a snowflake, the velocity distribution function must be expressed mathematically. Fortunately, all of the frequency histograms can be approximated enough by a linear combination of several normal distributions. The results for $M=0$ and $M=4$ are shown in the 3rd line and the mathematical expression, at the bottom of Fig. 9. In this expression, the coefficients of each normal distribution " $A_{i}$ " are determined by the normarized condition of the velocity distribution function and indicate the statistical weight of the corresponding normal distribution $N\left(V_{i}, \sigma_{i}\right)$. For example, the velocity distribution function of $M=0$ is decomposed into 4 elemental normal distributions $N(55.3,9.5), N(73.6,17.7), N(105.1$, 23.6) and $N(190.0,12.0)$, whose average fall velocities are $55.3 \mathrm{~cm} / \mathrm{s}, 73.6 \mathrm{~cm} / \mathrm{s}, 105.1 \mathrm{~cm} / \mathrm{s}$ and $190.0 \mathrm{~cm} / \mathrm{s}$ and the standard deviations, $9.5 \mathrm{~cm} / \mathrm{s}, 17.7 \mathrm{~cm} / \mathrm{s}, 23.6 \mathrm{~cm} / \mathrm{s}$ and $12.0 \mathrm{~cm} / \mathrm{s}$, respectively. The contribution rate of the distribution $N(55.3,9.5 \mathrm{~cm} / \mathrm{s})$ to the velocity distribution function $P(V / M) \triangle M \Delta V$ is about $15 \%$ and for $N(73.6,17.7), N(105.1,23.6)$ and $N(190.0,12.0), 43 \%, 35 \%$ and $6 \%$, respectively.

The expression of the distribution function by the elemental normal distribution functions is shown in Fig. 10, where the ordinate indicates the fall velocity and the abscissa, the rank of mass classified by $1 \mathrm{mg}$ interval in the same way as Fig. 3-M. The average fall velocity and the standard deviation are shown by full circles and segments respectively. The statistical weights are also indicated beside the full circles. The histogram at bottom right in the figure indicates

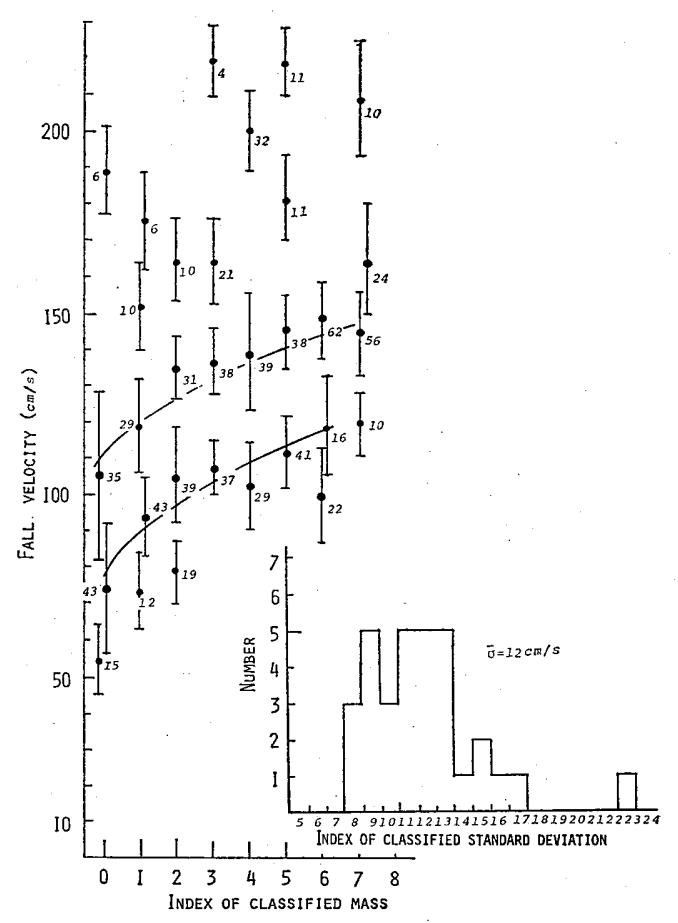

Fig. 10. The expression of the velocity distribution functions by a linear combination of the normal distributions. The figures on the abscissa have the same meaning as those in Fig. 3. The average value of each elementary normal distribution and the standard deviation are shown by the full circle and the segment, respectively. The histogram at bottom right shows the frequency distribution for the standard deviation. of the elementary normal distributions.

the frequency distribution for the standard deviations of the elemental normal distributions. The histogram indicates that the amount of the standard deviation changes from $8.8 \mathrm{~cm} / \mathrm{s}$ to $23.6 \mathrm{~cm} / \mathrm{s}$, but those normal distributions whose standard deviation lies at $10 \mathrm{~cm} / \mathrm{s} \pm 2 \mathrm{~cm} / \mathrm{s}$ account for more than $70 \%$ of the total, and the average standard deviation is $12.2 \mathrm{~cm} / \mathrm{s}$. The standard deviation, the average fall velocity and the statistical weight are also summarized in Table 3 . Both Fig. 10 and Table 3 indicate that the velocity distribution function of snowflakes with mass ranging from $M$ to $M+\Delta M$ is generally expressed by a linear combination of several 
Table 3 The average fall velocities, the standard deviations and the statistical weight of the elementary normal distributions.

\begin{tabular}{|c|c|c|c|c|c|c|}
\hline $\begin{array}{c}\text { Mass } \\
(\mathrm{mg})\end{array}$ & $\begin{array}{c}\text { Mean } \\
(\mathrm{cm} / \mathrm{s})\end{array}$ & $\begin{array}{c}\text { Stan. dev. } \\
(\mathrm{cm} / \mathrm{s})\end{array}$ & $\begin{array}{c}\text { Weight } \\
(\%)\end{array}$ & $\begin{array}{c}\text { Mean } \\
(\mathrm{cm} / \mathrm{s})\end{array}$ & $\begin{array}{c}\text { Stan. dev. } \\
(\mathrm{cm} / \mathrm{s})\end{array}$ & $\begin{array}{c}\text { Weight } \\
(\%)\end{array}$ \\
\hline $0 \sim 1$ & 55.3 & 9.5 & 15 & 73.6 & 17.7 & 43 \\
$1 \sim 2$ & 74.2 & 11.8 & 12 & 94.2 & 11.5 & 43 \\
$2 \sim 3$ & 79.4 & 8.8 & 19 & 105.7 & 13.4 & 39 \\
$3 \sim 4$ & 107.0 & 8.9 & 37 & 137.0 & 9.4 & 38 \\
$4 \sim 5$ & 102.6 & 12.5 & 29 & 140.4 & 16.7 & 39 \\
$5 \sim 6$ & 112.1 & 10.8 & 41 & 146.2 & 10.4 & 38 \\
$6 \sim 7$ & 98.7 & 13.1 & 22 & 118.3 & 14.1 & 16 \\
$7 \sim 8$ & 120.0 & 8.5 & 10 & 139.4 & 11.3 & 56 \\
\hline
\end{tabular}

\begin{tabular}{|c|c|c|c|c|c|c|}
\hline $\begin{array}{c}\text { Mass } \\
(\mathrm{mg})\end{array}$ & $\begin{array}{c}\text { Mean } \\
(\mathrm{cm} / \mathrm{s})\end{array}$ & $\begin{array}{c}\text { Stan. dev. } \\
(\mathrm{cm} / \mathrm{s})\end{array}$ & $\begin{array}{c}\text { Weight } \\
(\%)\end{array}$ & $\begin{array}{c}\text { Mean } \\
(\mathrm{cm} / \mathrm{s})\end{array}$ & $\begin{array}{c}\text { Stan. dev. } \\
(\mathrm{cm} / \mathrm{s})\end{array}$ & $\begin{array}{c}\text { Weight } \\
(\%)\end{array}$ \\
\hline $0 \sim 1$ & 105.1 & 23.6 & 35 & 190.0 & 12.0 & 6 \\
$1 \sim 2$ & 119.3 & 13.1 & 29 & 152.7 & 12.0 & 10 \\
$2 \sim 3$ & 135.5 & 9.0 & 31 & 165.0 & 11.0 & 10 \\
$3 \sim 4$ & 164.1 & 12.5 & 21 & 220.0 & 9.5 & 4 \\
$4 \sim 5$ & 200.0 & 11.0 & 32 & & & \\
$5 \sim 6$ & 183.3 & 12.5 & 11 & 220.0 & 9.5 & 11 \\
$6 \sim 7$ & 148.8 & 10.7 & 62 & & & 10 \\
$7 \sim 8$ & 165.5 & 15.4 & 24 & 210.0 & 15.8 & 10 \\
\hline
\end{tabular}

normal distributions including two main ones with statistical weight above $30 \%$.

Now let us call the main distribution with the larger average velocity the first normal distribution $N_{1}\left(\bar{V}_{i}, \sigma_{i}\right)$ and the other the second normal distribution $N_{2}\left(\bar{V}_{i}, \sigma_{i}\right)$ hereafter. The average fall velocities of both distributions $N_{1}\left(\bar{V}_{i}, \sigma_{i}\right)$ and $N_{2}\left(\bar{V}_{i}, \sigma_{i}\right)$ increase with the increasing of the rank of mass and the relation between them is also shown by full lines in Fig. 10. These relations can also be approximated by the following power functions :

$$
\begin{aligned}
V= & 292 D^{0.46} \ldots(2) \text { for the first normal } \\
& \text { distribution } \\
V= & 203 D^{0.39} \ldots(3) \text { for the second normal } \\
& \text { distribution. }
\end{aligned}
$$

From the above, we might conclude that more than $70 \%$ of the observed snowflakes have a fall velocity which shows either the first normal distribution $N_{1}\left(\bar{V}_{i}, \sigma_{i}\right)$ or the second $N_{2}\left(\bar{V}_{i}, \sigma_{i}\right)$, where the average velocity of which increases with the increase of mass as shown in Fig. 10, while the standard deviations are about $12 \mathrm{~cm} / \mathrm{s}$ regardless of the mass.

\section{The relation between the cross-sectional area and the mass, $S-M$ relation}

The cross-sectional area of the snowflake was determined by using the enlarged photograph of the cross section $(\times 5 \sim \times 10)$ in two different ways: one is by measuring the area of the cross section by a planimeter and the other, by cutting out the picture of the snowflake cross section and weighing it.

The relation between the cross-sectional area and the mass of a snowflake is shown in Fig. 11, where the ordinate and abscissa indicate the cross-sectional area $S\left(\mathrm{~mm}^{2}\right)$ and the mass $M(\mathrm{mg})$, respectively. The relation also shows wide dispersion, which seems to be due to the variety in the shape and fall pattern of the snowflake. The shape and fall pattern are usually not determined uniquely even if the snowflake grows under the 


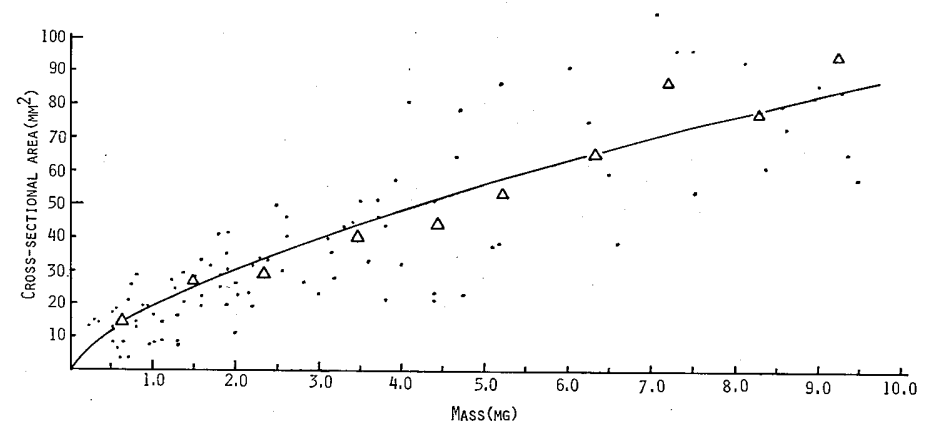

Fig. 11. The relation between the cross-sectional area and the mass. The average crosssectional area and the averaged mass for each sub-population of mass $M \mathrm{mg} \sim$ $(M+1) \mathrm{mg}$ are shown by open triangles. The full line is drawn with eye so as to fit the open triangles.

same environmental condition, but they are governed in terms of probabilities. Therefore, the dispersion of the $S-M$ relation may be canceled by the average of the mass and of the cross-sectional area and the relation between average mass and cross sectional area may be thought the relation for the idealized spherical snowflake having no direction qualities. Then, the population of the snowflakes is divided into some subpopulations with the successive mass intervals of $1 \mathrm{mg}$ in the same way as in the previous section, i. e. $0<M<1 \mathrm{mg}, 1 \mathrm{mg} \leqq M<2 \mathrm{mg}, \cdots$, and the average mass and cross-sectional area are separately calculated for each subpopulation. In this figure, the relation between the average cross-sectional area and the average mass is shown with open triangles. It can be approximated by the following equation :

$$
\bar{M}=0.012 \mathrm{~S}^{3 / 2} \text {. }
$$

Equation (4) can also be derived as follows:

Assuming that the average depth of the snowflake " $D$ " is replaced by

$$
D=A \bar{S}^{1 / 2},
$$

the mass can be expressed as

$$
\begin{aligned}
M & =\bar{\lambda} \bar{S} \bar{D} \\
& =A \bar{\lambda} \bar{S}^{3 / 2},
\end{aligned}
$$

where " $A$ " is a geometrical factor depending upon the shape of the snowfiake and " $\bar{\lambda}$ ", the average density of the snowflake. When we use 0.012 for $(A \times \bar{\lambda})$, equation ( 6$)$ agrees with equation (4). However, the average density " $\bar{\lambda}$ " and the geometrical factor " $A$ " cannot be determined separately, and then we must assume either a value of " $\bar{\lambda}$ " or a value of " $A$ ". If equation (4) or $S-\bar{M}$ curve shows the relation for the idealized spherical snowflake with diameter " $d$ " as mentioned above, $D=0.667 d$ and $A=0.75$ are easily found and then the $\bar{S}-\bar{M}$ curve corresponds with the average density of $0.016 \mathrm{~g} / \mathrm{cm}^{3}$. The average density of $0.016 \mathrm{~g} / \mathrm{cm}^{3}$ is nearly equal to the density of freshly fallen snow in the Hokuriku district and it may be a reasonable value for the damp snowflake.

Assuming that all of the snowflakes are spherical, many $S-M$ curves are drawn according to the various densities and their slope becomes the steeper for the lower densities or dryer snowflakes. Then, the snowflakes lying above the $\bar{S}-\bar{M}$ curve have densities lower than $0.016 \mathrm{~g} / \mathrm{cm}^{3}$ and those below the $\bar{S}-\bar{M}$ curve, densities greater than $0.016 \mathrm{~g} / \mathrm{cm}^{3}$.

On the other hand, assuming that the density is $0.016 \mathrm{~g} / \mathrm{cm}^{3}$ for all snowflakes, the snowflakes belonging to the region above the $\bar{S}-\bar{M}$ curve correspond to a tabulate type and those below the curve, to an oblate type, because the former have a large crosssectional area compared with the spherical snowflakes, and the latter have a smaller one, though the two have the same mass. The fall velocities of the snowflakes in the 
region above the $\bar{S}-\bar{M}$ curve (to be called the upper-group) are smaller than those in the region below it (the lower-group) in either assumption mentioned above. Then, the average velocities of the upper-group and the lower-group are calculated for each subpopulation classified by successive mass intervals of $1 \mathrm{mg}$ and are compared with those of the first and second main normal distributions $N_{1}\left(\bar{V}_{i}, \sigma_{i}\right), N_{2}\left(\bar{V}_{i}, \sigma_{i}\right)$ in Fig. 12. In Fig. 12, the ordinate is the same as in Fig. 6 and the average fall velocities of the first and second normal distribution are shown by full and open squares respectively. On the other hand, the average fall velocities of lower and upper-group are shown by the

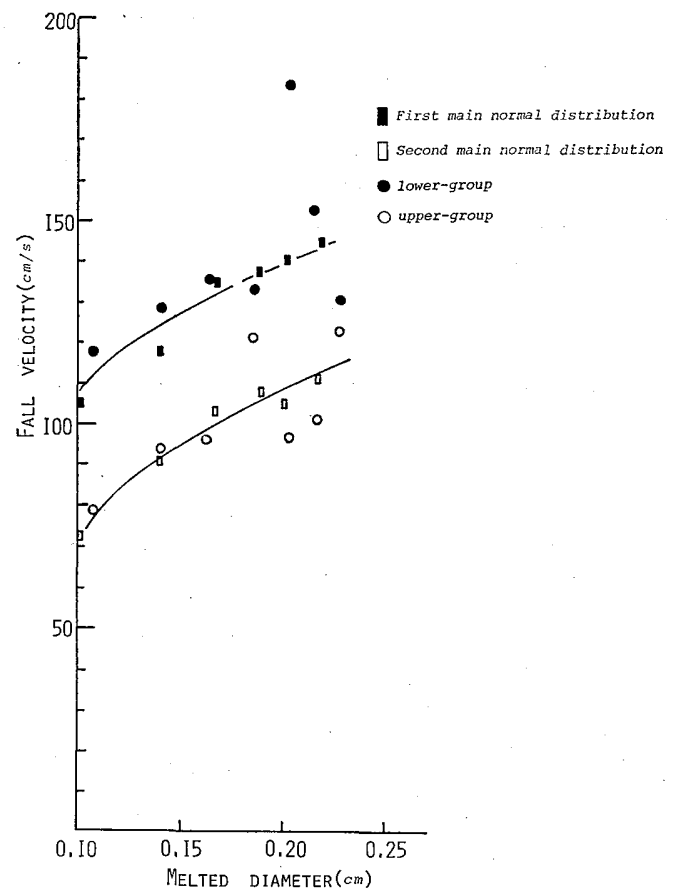

Fig. 12. A comparison of the average values of the first and second main normal distri. butions with the average fall velocities of snowflakes belonging the O-group and $\mathrm{T}$-group. The average values of the first and second main normal distributions are shown by full and open squares, respectively. The average fall velocities for O-group and T-group are also shown by the full and open circles, respectively. full and open circles respectively.

It is interesting that the average fall velocities of the first normal distribution roughly agree with those of the lower-group over the whole range of the mass and those of the second normal distribution agree with those of the upper-group. From the fact, we can say that the population can be divided two main sub-populations, one of them corresponds to the lower-group and the average fall velocity obeys the first normal distribution, other corresponds to uppergroup and the average fall velocity obeys the second normal distribution.

Unfortunately, the physical meaning of the fact described above is not clear at present but some explanations are offered in the next section.

\section{Discussion}

There still remain some problems to be dealt with in our work. First of all we ought to examine whether or not the velocity distribution function can always be expressed by a linear combination of several normal distribution. Second, if the above fact holds, we ought to explain it physically. It is difficult fully to discuss these problems but we can offer some physical considerations about them as follows :

Figs. 13-a and -b show the decompositions of the velocity distribution functions on 28th of Jan. 1978 and 4th of Feb. 1979 by normal distribution functions, respectively. (On other snowfalls, we could not get enough data to get a velocity distribution function). These figures have similar tendencies shown in Fig. 10. Namely, the distribution functions are also approximated by the linear combination of the normal distribution including two main normal distribution functions and their standard deviations are constant at about $12 \mathrm{~cm} / \mathrm{s}$, regardless of snowfalls and the mass of snowflakes though the average fall velocities depend upon the snowfalls and the masses. The figures suggest that the velocity distribution function can generally be approximated by a linear combination of 


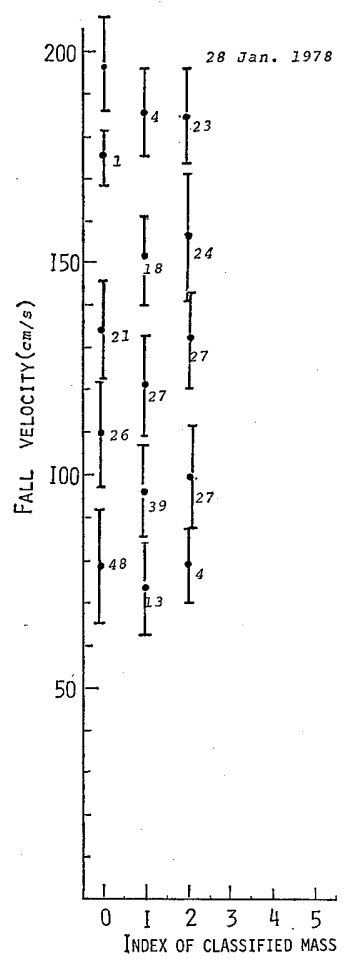

(a)

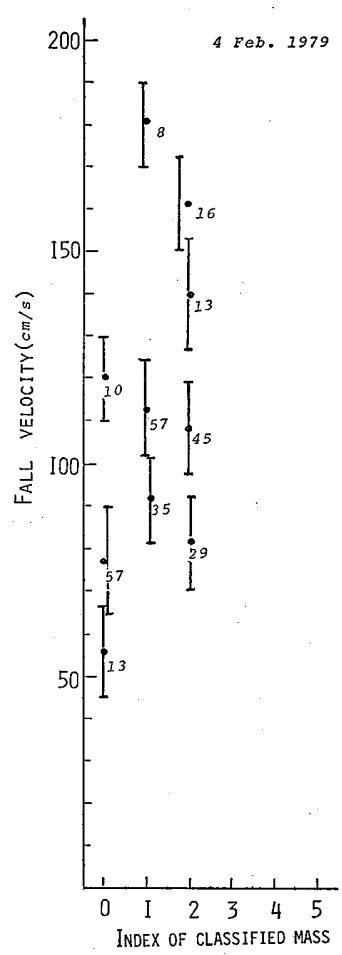

(b)
Fig. 13. The velocity distribution for the subpopulation which include only snowflakes observed at temperature $0^{\circ} \mathrm{C}$ and below. several normal distribution functions.

In section 6 , we divided the population of snowfalls into several sub-populations with successive mass intervals of $1 \mathrm{mg}$ in order to obtain the velocity distribution function, but these sub-populations contain still various factors affecting fall velocity, such as the degree of melting, riming of snowflakes and so on.

If the sub-population can be subdivided into finer homogeneous sub-populations according to other independent factors and the velocity distribution functions for these homogeneous sub-populations are separately represented by the normal distribution function, the velocity distribution function of the original population may be expressed by a linear combination of these normal distribution functions. However, the number of available sub-populations quickly decreases with the repetition of such subdivision of the original population, because the individual refined population becomes poor in the number of data.

As an example, let us consider the refined population which contains only the snowflakes at temperature $0^{\circ} \mathrm{C}$ or below. In our case, the sub-populations of $M=0$ and $M=1$ contain
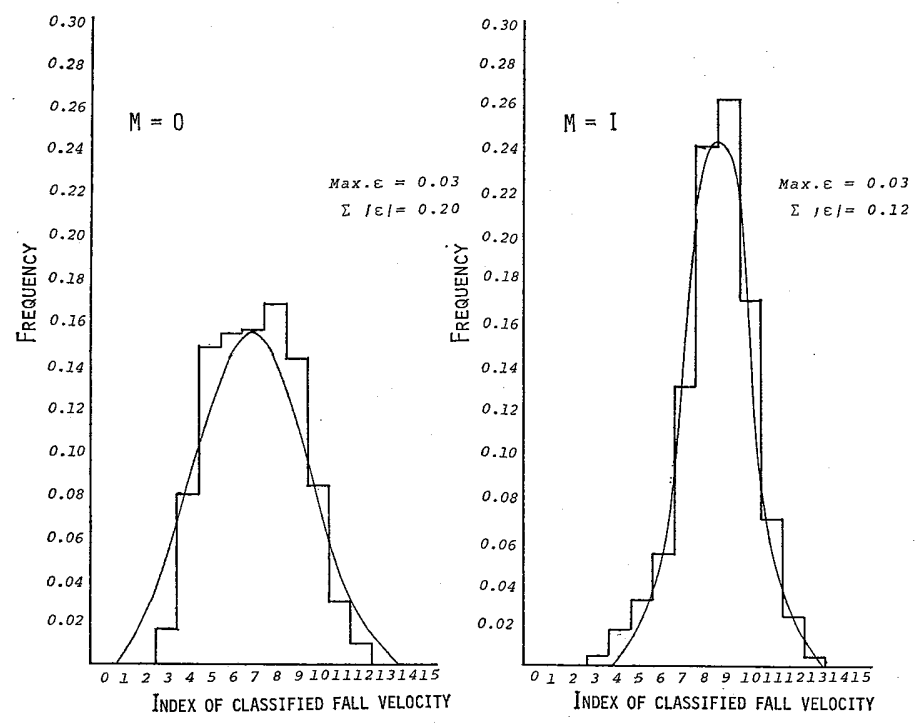

Fig. 14. The expressions of the velocity distribution of 28th of Jan. 1978 and 4th of Feb. 1979 by a normal distribution function. The meanings of the coordinate axes and the symbols are the same as in Fig. 10. 
only 45 and 29 snowflakes respectively and those for $M>2$ cannot be defined.

The velocity distribution functions for $M=0$ and $M=1$ could be approximated by one normal distribution function as shown in Fig. 14. The average fall velocity and the standard deviation of the normal distribution functions are $70 \mathrm{~cm} / \mathrm{s}$ and $26 \mathrm{~cm} / \mathrm{s}$ for $M=0$ and $90 \mathrm{~cm} / \mathrm{s}$ and $14 \mathrm{~cm} / \mathrm{s}$ for $M=1$, respectively. The discrepancies between the observed velocity distribution function and the corresponding normal distribution function are 0.03 in maximum value and 0.20 or less in the sum total of the absolute discrepancy. These discrepancies may not be very serious errors. The fact may suggest that the velocity distribution function of finer homogeneous sub-population can be expressed by a normal distribution function.

It is worth noting that these average velocities agree roughly with those of the second normal distribution function in Fig. 10 , namely, the great part of the snowflakes belonging to the second main normal distributions $N_{2}\left(\bar{V}_{0}, \sigma_{0}\right)$ and $N_{2}\left(\bar{V}_{1}, \sigma_{1}\right)$ may be thought ones observed at temperature $0^{\circ} \mathrm{C}$ or below.

Fig. 14 may also suggest that the velocity distribution function of a finer homogeneous sub-population can be approximated by a normal distribution function.

Acknowledgements:-For the preparation of this paper, we would like to thank Mr. J. Kubo, Chief Researcher in Physical Meteorology Division, and Dr. M. Kanō, Upper Atmosphere Physics Division, Meteorological Research Institute, for valuable discussions, and also Dr. H. Kuriyama, Director, Dr. T. Kimura and Mr. K. Koide, Institute of Snow and Ice Studies, National Research Center for Disaster Prevention, for providing us with various facilities in carrying out the observations.

Appendix The approximation of the velocity distribution function with a linear combination of normal distribution functions was done as follows:
We so determine the average velocity, the standard deviation of the normal distribution and the statistical weight that the normal distribution function agree with the frequency histogram of fall velocity at three consecutive velocity intervals including the largest (smallest) one.

The normal distribution function is deducted from the frequency histogram and the residuary histogram (second histogram) is made.

The next normal distribution function is determined by repeating the same procedure in sequence.

The accuracy of the approximation can be estimated by the final residue to which the normal distribution function can not be applied.

In our case, the accuracy of the approximation was generally better than several percents.

\section{References}

Fujiwara, M., 1975: Note on collision frequency of snowflakes. J. Met. Soc. Japan, 75th Anniversary volume, 57-64.

Hosler, C. L., Jensen, D. C. and Goldshlak, L., 1957 : On the aggregation of ice crystals to form snow. J. Met. Soc., 14, 415-420.

Imai, I., M. Fujiwara, I. Ichimura and Y. Toyama, 1955: Radar reflectivity of falling snow. Pap. Met. Geophys. 6, 130-139.

Kajikawa, M., 1974: Measurement of falling velocity of snowflakes. Res. Rep. of Akita Tec. college, No. 9, 83-87.

Langleben, M.P., 1954: The terminal velocity of snowflakes. Quart. J. Roy. Met. Soc., 80, 174-181.

Litvinov, I. V., 1956: Determination of the steadystate velocity of falling snow particles. Izv. Akad. Nauk. SSSR Geopys. Ser. 7, 853-856.

Magono, C., 1954: On the falling velocity of solid precipitation elements. Sci. Rep. Yokohama Nat. Univ. Sec. I, No. 3, 33-40.

Magono, C., 1953: On the growth of snowflake and graupel. Sci. Rep. Yokohama, Nat. Univ. Sec. I., No. 2, 18-40.

Magono, C. and T. Nakamura, 1965: Aerodynamic studies of falling snowflakes. J. Met. Soc. Japan, 43, 139-147.

Sasyo, Y., 1971: Study of the formation of pre- 
cipitation by the aggregation of snow particles flakes. Pap. Met. Geophys., 22, 69-142. and the accretion of cloud droplets on snow-

\title{
雪片の落下速度の確率分布関数について
}

\author{
物理気像研究部
}

佐 藤 純男・松尾敬世

落下速度の分散を考虑して, 雪片の成長過程を論ずるには, 落下速度の確率分布関数, 即ち, 質量 $M \sim M+\Delta M$ の雪片が落下速度 $V \sim V+\Delta V$ をるつ, 条件付確率 $P(V \mid M) \Delta M \cdot \Delta V$ を求める必要がある。

このために，雪片の落下速度，質量，垂直断面積の同時測定を行なった。測定は，1978年 1 月 $27 〜 28,29$ 日〜30 日, 1979年 2 月 2 日, 2 月 4 日の 4 回の降雪について行なった。観測場所は, 新潟県, 長岡市の雪害実験研究所構 内である。

観測装置の概観は Fig. 1 亿示した。落下速度は，一定間隔にセットされた2つの photo-coupler 間を落下する 雪片の通過時間から求めた。断面積は，photo-coupler に同調させた，単発フラッシュによる写真撮影から測定し， 質量の決定は，濾紙法に依った。

各降雪毎に求めた，雪片の質量，断面積，落下速度の頻度分布を Fig. 3 と示した。これから，各降雪の粒度特 性が推定出来る。又, 質量 $M(\mathrm{mg})$, 落下速度 $V(\mathrm{~cm} / \mathrm{s})$ のデーターを $M-V$ 座標にプロットして, Fig. 4-a〜d を得た。ずれの降雪でも， $M-V$ 関係は大きな分散を示している。特に質量のちいさい雪片ほど分散は大きい。 これは, melting の度合が，落下速度に大きく影響するためと考光られる。(Fig. 5)

安定した速度分布関数を得るため, 上記 4 降雪を一括して扱った。この母集団に対する, 質量, 断面積及び落下 速度の頻度分布はFig. 8 に示した。これらは北陸の雪片に対する平均特性を示するのと考兄てよからう。

質量〜落下速度の同時観測データー 327 ケを，質量間隔 $\Delta M=1 \mathrm{mg}$ の部分母集団に分け夫々の部分母集団につ いて，速度の頻度分布を求め，これを速度分布関数 $P(V \mid M) \Delta M \Delta V$ とした。ここで速度間隔 $\Delta V=10 \mathrm{~cm} / \mathrm{s}$ とと っ。速度分布関数の特質は

(1) すべての速度分布関数 $P(V \mid M) \Delta M \cdot \Delta V(M=0,1,2, \cdots)$ は, 数らの要素 Gauß 分布の一次結合で示すこ とが出来た (Fig. 9, 10)

(2) これらの要素 Gauß 分布の中で，速度分布関数に $30 \%$ 以上寄与する 2 つの主 Gauß 分洧が存在した。この 主 Gauß 分布の中，大きい平均値をもつものを第 1 種 Gauß 分布，ちいさい平均速度のものを第 2 種 Gauß 分布と 呼んだ。

(3) 第 1 種, 第 2 種 Gauß 分布の平均落下速度は質量 $M$ (融解值径 $D$ ) と共に增加し, 第 1 種 gauß 分布に対し

第 2 種 Gauß 分布に対し

$$
\bar{V}=292 D^{0.46} \text {, }
$$

$$
\bar{V}=203 D^{0.39} \text {, }
$$

で近似出来た。一方標準偏差は, 質量に関係なく，ほぼ一定 $12 \mathrm{~cm} / \mathrm{s}$ であった。從って，今回観測した，雪粒子 の 70〜80\% は，標準偏差 $12 \mathrm{~cm} / \mathrm{s}$ ，平均速度 $V_{1}$ あるいは $V_{2}$ をるつ正規分布のいずれかに属しているといえる。

質量〜断面積の関係は Fig. 11 に示した。この関係も，大きな分散を示しているが，平均的に

$$
M=0.012 S^{3 / 2} \text {, }
$$

で示すことが出来た。この係数 0.012 は, 雪片の密度及び形の関数である。 